\title{
Association between binge drinking, type of friends and gender: A cross-sectional study among Brazilian adolescents
}

\author{
Patrícia M Zarzar ${ }^{*}$, Kelly O Jorge ${ }^{1}$, Tuula Oksanen ${ }^{2}$, Miriam P Vale ${ }^{1}$, Efigênia F Ferreira ${ }^{3}$ and Ichiro Kawachi
}

\begin{abstract}
Background: Hazardous drinking among adolescents is a major public health concern. The purpose of this study was to examine the prevalence of binge drinking/alcohol consumption and its association with different types of friendship networks, gender and socioeconomic status among students in Belo Horizonte, Minas Gerais, Brazil.

Methods: We conducted a cross-sectional study on a representative random sample of 891 adolescents (41\% male, aged 15-19 years) from public and private schools in 2009-2010. Information on friendship networks and binge drinking was collected using two validated self-administered questionnaires: the Integrated Questionnaire for the Measurement of Social Capital and the first 3 items in the Alcohol Use Disorders Identification Test (AUDIT C). We used the area-based Social Vulnerability Index (SVI), mother and father's educational background, and the type of school to assess socioeconomic status. The chi-squared test was used to examine the associations between sample characteristics or the type of friends and binge drinking ( $p$-values $<0.05$ were considered statistically significant). Ordinal logistic regression was used to estimate the association between binge drinking and the independent variables.

Results: A total of 321 (36\%) adolescents reported binge drinking (5 or more drinks in one occasion), and among them, 233 (26.2\%) adolescents reported binge drinking less than monthly to monthly, and 88 (9.9\%) weekly to daily. Binge drinking was associated with being male $(\mathrm{OR}=1.52,95 \% \mathrm{Cl} 1.01-2.28)$ and with living in a low vulnerability area (having the best housing conditions, schooling, income, jobs, legal assistance and health) $(\mathrm{OR}=1.66,95 \% \mathrm{Cl}$ 1.05-2.62). Students who reported that their closest friends were from school (as opposed to friends from church) had an increased risk of binge drinking ( $\mathrm{OR}=3.55,95 \% \mathrm{Cl} 1.91-5.87)$. In analyses stratified by gender, the association was significant only among the female students.
\end{abstract}

Conclusions: The prevalence of binge drinking was high in this sample of Brazilian adolescents, and gender, low social vulnerability and friendship network were associated with binge drinking.

Keywords: Alcohol drinking, Friendship, Adolescent behavior, Socioeconomic factors, Epidemiology

\section{Background}

Binge drinking among adolescents continues to be a significant public health concern due to its high prevalence in several countries, including Thailand (33.0.\%), the United Kingdom (47.0\%), Germany (26.9\%), Sweden (30.8\%), and Brazil (34.5\%) [1-5]. In Brazil, alcohol use and binge drinking represent important public health

\footnotetext{
* Correspondence: patyzarzar@hotmail.com

${ }^{1}$ Department of Pediatric Dentistry and Orthodontics, Faculty of Dentistry, Universidade Federal de Minas Gerais, Av. Antonio Carlos, 6627 CEP: 31270901, Belo, Horizonte/MG, Brazil

Full list of author information is available at the end of the article
}

challenges because adolescents can easily purchase alcohol even though it is prohibited by law [6]. Binge drinking among adolescents is associated with the disruption of brain development [7], increased risk of alcoholism in adulthood, and increased risks for cardiovascular disease [8], disability and death [9].

Binge drinking is usually performed in groups; therefore, peers play a role in promoting binge drinking, perhaps due to peer selection or peer influence (socialization). Binge drinking has been associated with characteristics of the adolescents' friendship networks [10-13]. Over the course of a

\section{Biomed Central}


lifetime, friendships can direct development through support, modeling, and assistance, but the significance of friendships is heightened during adolescence [14]. Peers have the potential to exert either positive or negative influences on behavior, depending on the behavior endorsed by the peer group $[15,16]$. During adolescence, schools may set the standards for the behavioral patterns and attitudes of the youths $[17,18]$, and thus, students may have shared influences on their health and health-related behaviors [18]. Given the social nature of this behavior, it is not surprising that some previous work has identified associations between binge drinking and the social context, such as schools, family, and churches [10,11,13,15,19-21]. Social network effects may have both positive and negative health implications for alcohol consumption patterns, depending on the context and the circumstances [15].

Despite the preponderance of research examining the influence of peer relationships on binge drinking, few studies have evaluated the link between drinking behavior and the specific types of social relationships represented by peers. In other words, not all friendship ties are equally influential in shaping adolescent behaviors, and the aim of our study was to distinguish between the different types of friendships in various contexts $[10,11,13,15,19-21]$.

Some of these studies $[10,11,13]$ examined the influence of the peer group on alcohol consumption in adolescents, but they were limited to investigating just the school based peer network. However, since the influence of peer networks is not necessarily limited to the school setting, it is important that the multiple friendship networks be investigated, including those based on relationship in groups such as the church or participation in sports [19]. Understanding the relative influence of different types of peer networks on adolescent behavior can be a valuable starting point in developing interventions to modify adolescent behavior such alcohol consumption. Indeed it is more effective sometimes to intervene at the level of peer group rather than the individual, since the group can reinforce any health promotion message and provide social support for maintaining the new behavior [19].

In this paper, we examined the prevalence of binge drinking/alcohol consumption and its association with different types of friendship networks in different contexts (school, home, church, hobby groups) among male and female students in Belo Horizonte, Minas Gerais, Brazil.

\section{Methods}

\section{Study design and participants}

We designed a cross-sectional study to examine social and friendship networks and binge drinking among 936 adolescents aged 15 to 19 years attending public schools $(\mathrm{n}=717,81 \%)$ and private schools $(\mathrm{n}=174,19 \%)$ in the city of Belo Horizonte between August 2009 and February 2010. Belo Horizonte is the state capital of Minas
Gerais, Brazil, and it has approximately two million inhabitants and is geographically divided into nine administrative districts (Brazilian Institute of Geography and Statistics/IBGE) [22]. A sample of 936 adolescents was randomly selected using a two stage stratified cluster sampling approach. The first stage was the random selection of eighteen schools (9 public and 9 private schools) in the 9 administrative districts. The second stage was the random selection of 34 classrooms within the schools. The sample size was calculated to yield a standard error of $4.0 \%$. To calculate the required sample size for our survey, we used a $50 \%$ prevalence of alcohol consumption, which was based on statistical considerations. We used the rule suggested by others [23,24] of assuming a prior prevalence of $50 \%$ to calculate the same size.

The minimum sample size needed to satisfy the requirements was estimated to be 600 individuals. To minimize the potential losses during data collection, the sample was increased by $20 \%(n=720)$. A design effect of 1.3 was applied to increase the precision because a multistage sampling method rather than random sampling was adopted [25]. Thus, the sample comprised 936 adolescents.

\section{Survey administration}

Self-administered questionnaires were distributed in the classroom by a researcher and assistant who collected the response envelopes immediately after being the questionnaires were completed. They explained that the responses would remain anonymous and be treated confidentially. To guard against biases that might occur due to variability in reading proficiencies, the principal investigator (K.O.J.) read aloud each question. The students could refuse to participate and return the unfilled questionnaires inside the envelopes. Among those who submitted envelopes, $4.8 \%$ of the participants (45 students) had either refused to participate or had submitted incomplete questionnaires (with 891 adolescents remaining in the study)

\section{Assessment of alcohol consumption}

For this study, the AUDIT C (the first 3 questions of the AUDIT instrument that were related to the frequency and amount of alcohol consumed) was used because it could be employed as a stand-alone screening measure to detect hazardous drinkers among adolescents [26,27]. The Alcohol Use Disorders Identification Test (AUDIT) is a frequently used simple method for screening individuals to determine whether they were consuming excessive amounts of alcohol [26,28]. This questionnaire had been validated in Brazil [29] and had been used in a representative sample aged 15 years and over in two southeastern cities of Brazil [30,31]. This screening tool helps to identify whether an individual exhibits hazardous (or risky) 
drinking, harmful drinking or alcohol dependence. Binge drinking was defined as 5 or more drinks on one occasion [5]. One drink represents, on average, a can of beer or 350 $\mathrm{ml}$ of draft beer or $90 \mathrm{ml}$ of wine, or $30 \mathrm{ml}$ of a distilled beverage. Each drink contains approximately 10-12 g of alcohol [32]. The survey respondents were shown pictures of standard portions of different types of alcoholic beverages (beer, wine, whisky, and "cachaça", a popular distilled spirit in Brazil).

We assessed binge drinking using the question "How often do you have five or more drinks on one occasion?" The response options were: Never, Less than monthly, Monthly, Weekly, and Daily or almost daily. Those who answered "Never" were coded as 0 in the analysis, "Less than monthly" and "Monthly" were coded as 1 , and those who reported "Weekly" and "Daily or almost daily" frequency were coded as 2 . Because binge drinking may result in more negative consequences than low to moderate drinking [33], we used binge drinking as our dependent variable.

The remaining items on the AUDIT $\mathrm{C}$ instrument were as follows: a) "How often did you have a drink containing alcohol in the past year?" The response options for the frequency of alcohol consumption were: "Never", "Monthly or less", "2 to 4 times a month", "2 to 3 times a week", and " 4 or more times a week"; and b) "How many drinks containing alcohol did you have on a typical day when you were drinking?" The response options for the amount of alcohol consumption were " 1 or 2 ", " 3 or 4 ", "5 or 6", “7, 8, or 9", and "10 or more".

\section{Assessment of social and friendship networks}

The Integrated Questionnaire for the Measurement of Social Capital (CS-IQ) is a validated questionnaire developed by the World Bank in 2003 to assess social capital [34]. The instrument consists of 27 questions that are divided into 6 domains (groups and networks, trust and solidarity, collective action and cooperation, information and communication, cohesion and social inclusion, and empowerment and political action) [34]. The CS-QI domain selected for this study was the groups and networks domain because the study objective was to assess social behaviors related to membership in adolescent peer networks. This questionnaire was applied in a pilot test, and the students did not suggest any changes to the questionnaire. The respondents were asked to identify their most important group of close friends, and the answers were aggregated according to the most frequent response: friends from school, family, church and hobbies or other activities (sports, theatre, dances and music activities). The adolescents were also asked whether the majority of their friends' had the same occupation and educational background. Respondents were asked about the number of groups of friends they had, and the answers were dichotomized as less than 2, and 2 or more groups of friends.

\section{Assessment of socioeconomic status (SES)}

The Social Vulnerability Index (SVI) was used to assess the residential socioeconomic status. This index measures social exclusion in the city of Belo Horizonte. The City Hall database of SVI scores for each district was used based on the address of each student (derived from the survey) [35].

According to the theoretical framework that supported the development of the SVI, this index has 20 variables grouped into five "dimensions of citizenship": (a) access to housing and basic infrastructure, (b) access to education, (c) access to income and employment, (d) access to legal assistance and (e) access to health, food security and welfare (35). The index categorizes residential areas into 5 classes (class I to class V), with class I indicating the highest degree of social vulnerability (the worst housing conditions, schooling, income, jobs, legal assistance and health) and class $\mathrm{V}$ indicating the lowest degree of social vulnerability (most advantageous conditions) [31,35-41]. The SVI has been standardized for use in characterizing area-level socioeconomic status in Brazil in several studies.

The mother and father's educational attainment were chosen as an indicator of individual socioeconomic status because of its association to alcohol consumption/binge drinking in adolescents [42-44]. The level of education was derived from the students' survey responses regarding the years of schooling their mothers and fathers had received. The respondents who reported that their mothers and fathers had studied for a period of between 0 to 7 years were coded as 0 , and those who reported 8 or more years were coded as 1 . The cut-off threshold was the median response.

The type of school was also used as a socioeconomic indicator. Although type of school is a crude assessment, wealthy adolescents in Brazil are enrolled in private schools because most Brazilian public schools are known to have less educational resources than private ones [5]. Moreover, Brazilian national epidemiological studies and others studies developed in Brazil's southeastern cities have used this variable as an indicator of socioeconomic status [45-49]. In a recent study, the type of school was used as a socioeconomic indicator, and the authors concluded that this variable can be useful in studies involving children in Brazil [50].

\section{Ethics}

This study was approved by the Ethics Committee of the Universidade Federal de Minas Gerais. Authorization was obtained from the schools to perform the research. The participants and their parents/guardians signed the informed consent. 


\section{Statistical analysis}

The chi-squared test was used to study the associations of sample characteristics or the type of friends and binge drinking ( $p$-values $<0.05$ were considered statistically significant).

We used binary logistic regression analysis to examine the association of binge drinking and the type of friends. The results were expressed as odds ratios (OR) and 95\% confidence intervals (CI). Each type of most important group of friends was compared to friends from hobbies/ other in relation to binge drinking at frequencies ranging from less than monthly to monthly and also from weekly to daily.

An ordinal logistic regression model was used because our dependent variable was ordinal (the proportional odds model - logit link function). This model compares the likelihood of a response equal or less than a certain category with the likelihood of a highest response based on the odds ratio calculation [51,52]. The inclusion criterion was a $p$ value less than 0.20 in the results of the bivariate analysis. The final model included all variables regardless of their $p$-values. Declines Homogeneity test and multi-colinearity test was performed with Pearson adjustments to analyze the validity of the final model. Because some studies have suggested that peer drinking has a greater impact on females than males [53,54], we conducted additional ordinal logistic regression models stratified by gender using the Statistical Package for the Social Sciences (SPSS for Windows, version 17.0, SPSS Inc., Chicago, IL, USA). The ordinal logistic regression models were controlled for age, gender, type of school, mother and father's educational background and SVI.

\section{Results}

The frequency of alcohol consumption was as follows: 212 (23.8\%) adolescents reported consuming alcoholic beverages monthly or less frequently, 154 (17.3\%) consumed alcohol 2 to 4 times a month, and $82(9.2 \%)$ adolescents reported drinking alcohol 2 or more times per week. Overall, the prevalence of any alcohol use during the past year was $50.3 \%(\mathrm{~N}=448)$ in the sample of $16-19$ year old adolescents.

The amount of alcoholic beverages consumed in a typical day when drinking alcohol was as follows: 123 (13.8\%) participants reported drinking 2 to 8 or more drinks. Binge drinking was reported by 321 (36\%) adolescents; of these adolescents, 233 (26.2\%) reported binge drinking less than monthly to monthly and $88(9.9 \%)$ reported binge drinking weekly to daily.

Table 1 shows the distribution of the sample based on the prevalence of the friendship network and by background characteristics. The majority of adolescents who lived in more vulnerable areas (Classes I and II) reported that the majority of their group of friends/close friends were from church, while those who lived in less vulnerable areas (Classes IV and V) reported that their most important group of close friends were from family and school networks $(\mathrm{p}<0.001)$. Adolescents who reported that the majority of their groups of close friends were from church had mothers and fathers whose educational background was less than 8 years of study $(\mathrm{p}<0.001)$.

Table 2 shows the association between binge drinking (less than monthly to monthly and weekly to daily) and each type of most important groups of close friends compared with friends from hobbies/other friends. Compared with those who had their most important groups of friends from hobbies and other activities, the adolescents females who reported that their most important groups of friends were from school were 2.75 times more likely to be binge drinking weekly to daily $(\mathrm{OR}=2.75$, 95\% CI 1.36-5.53), and 2.99 times more likely to be binge drinking less than monthly to monthly $(\mathrm{OR}=2.99$, 95\% CI 1.87-4.78). The association was not significant among the adolescent males for binge drinking weekly to daily $(\mathrm{OR}=1.64,95 \% \mathrm{CI} 0.72-3.74)$ and binge drinking less than monthly to monthly $(\mathrm{OR}=1.26$, 95\% CI 0.66-2.39). The female participants who reported that their most important groups of close friends were from church (as opposed to friends from hobbies/other activities) were 0.30 less likely to be binge drinking weekly to daily $(\mathrm{OR}=0.30$, 95\% CI $0.12-0.73)$ and 0.37 less likely to be binge drinking less than monthly to monthly $(\mathrm{OR}=0.37$, 95\% CI 0.22-0.63). This association was not significant among the male participants for binge drinking weekly to daily $(\mathrm{OR}=0.72,95 \%$ CI 0.29-1.82) nor for binge drinking less than monthly to monthly $(\mathrm{OR}=0.59$, 95\% CI 0.29-1.21).

Table 3 shows the association between binge drinking and friendship networks. The adolescents who reported that the most important groups of close friends were from school (as opposed to friends from church) had a higher likelihood of binge drinking $(\mathrm{OR}=3.55$, 95\% CI 1.91-5.87). In analyses stratified by gender, the association was significant only among the female participants $(\mathrm{OR}=3.70,95 \%$ CI 1.84-7.45). The adolescent males who reported having more than 2 groups of friends had increased odds of binge drinking (adjusted OR $=2.21,95 \%$ CI 1.00-4.87) compared with those who reported having less than 2 groups of friends. Adolescents from low vulnerability areas (best social and economic conditions) had 1.66 times higher odds of binge drinking (adjusted OR $=1.66,95 \%$ CI 1.05-2.62).

\section{Discussion}

In a random sample of 891 Brazilian adolescents 15 to 19 years of age, half of the participants reported alcohol consumption during the past year. One-third of the participants reported binge drinking. Having their most important 
Table 1 Distribution of the sample based on the prevalence of friendship network and by background characteristics in Belo Horizonte, Minas Gerais, Brazil, $2010(N=891)$

\begin{tabular}{|c|c|c|c|c|c|c|c|c|c|}
\hline & & \multicolumn{8}{|c|}{ Most important groups of close friends } \\
\hline \multicolumn{2}{|c|}{ Independentvariables } & $\begin{array}{c}\text { School } \\
\text { n (\%) }\end{array}$ & $\begin{array}{l}\text { Family } \\
\text { n (\%) }\end{array}$ & $\begin{array}{c}\begin{array}{c}\text { Hobbies and } \\
\text { others }\end{array}{ }^{* *} \\
\mathbf{n}(\%)\end{array}$ & $\begin{array}{c}\text { Church } \\
\text { n (\%) } \\
\end{array}$ & & $\begin{array}{l}\text { Total } \\
\text { n (\%) }\end{array}$ & *p-value & $\begin{array}{l}\text { Degrees of } \\
\text { freedom }\end{array}$ \\
\hline & & & & & & & & & \\
\hline Binge drinking & Never & $98(24.7)$ & $92(23.2)$ & $64(16.2)$ & $142(35.9)$ & $396(100)$ & & & \\
\hline & Less than monthly to monthly & $74(42.0)$ & $42(23.9)$ & $26(14.8)$ & $34(19.3)$ & $176(100)$ & 28.978 & 0.000 & 6 \\
\hline & Weekly to daily & $29(42.6)$ & $15(22.1)$ & $11(16.2)$ & $13(19.1)$ & $68(100)$ & & & \\
\hline & Total & $201(31.4)$ & $149(23.3)$ & $101(15.8)$ & $189(29.5)$ & $640(100)$ & & & \\
\hline \multirow[t]{4}{*}{ Age } & 15 to 16 years old & $109(27.6)$ & $104(26.3)$ & $63(15.9)$ & $119(30.1)$ & $395(100)$ & & 0.065 & 6 \\
\hline & 17 years old & $64(38.3)$ & $34(20.4)$ & $22(13.2)$ & $47(28.1)$ & $167(100)$ & 11.873 & & \\
\hline & 18 to 19 years old & $28(35.9)$ & $11(14.1)$ & $16(20.5)$ & $23(29.5)$ & $78(100)$ & & & \\
\hline & Total & $201(31.4)$ & $149(23.3)$ & $101(15.8)$ & $189(29.5)$ & $640(100)$ & & & \\
\hline \multirow[t]{3}{*}{ Gender } & Male & $71(31.8)$ & $46(20.6)$ & $48(21.5)$ & $58(26.0)$ & $223(100)$ & 9.647 & 0.022 & 3 \\
\hline & Female & $130(31.2)$ & $103(24.7)$ & $53(12.7)$ & $131(31.4)$ & $417(100)$ & & & \\
\hline & Total & $201(31.4)$ & $149(23.3)$ & $101(15.8)$ & $189(29.5)$ & $640(100)$ & & & \\
\hline \multirow[t]{3}{*}{ Type of School } & Public & $153(31.2)$ & $84(17.1)$ & $79(16.1)$ & $175(35.6)$ & $491(100)$ & 61.354 & 0.000 & 3 \\
\hline & Private & $48(32.2)$ & 65 (43.6) & $22(14.8)$ & $14(9.4)$ & $149(100)$ & & & \\
\hline & Total & $201(31.4)$ & $149(23.3)$ & $101(15.8)$ & $189(29.5)$ & $640(100)$ & & & \\
\hline \multirow{4}{*}{$\begin{array}{l}\text { Mother's educational } \\
\text { background }\end{array}$} & O to 7 years of study & $64(31.4)$ & $24(11.8)$ & $28(13.7)$ & $88(43.1)$ & $204(100)$ & 40.156 & 0.000 & 3 \\
\hline & 8 or more years of study & $106(31.7)$ & $106(31.7)$ & $49(14.7)$ & $73(21.9)$ & $334(100)$ & & & \\
\hline & Total & $170(31.6)$ & $130(24.2)$ & $77(14.3)$ & $161(29.9)$ & $538(100)$ & & & \\
\hline & O to 7 years of study & $66(29.9)$ & 35 (15.8) & $31(14.0)$ & $89(40.3)$ & $221(100)$ & 36.996 & 0.000 & 3 \\
\hline \multirow{3}{*}{$\begin{array}{c}\text { Father's educational } \\
\text { background }\end{array}$} & 8 or more years of study & $96(35.2)$ & $90(33.0)$ & $38(13.9)$ & 49 (17.9) & $273(100)$ & & & \\
\hline & Total & $162(32.8)$ & $125(25.3)$ & $69(14.0)$ & $138(27.9)$ & $494(100)$ & & & \\
\hline & High vulnerability (class I and II) & $90(29.3)$ & $38(12.4)$ & $57(18.6)$ & $122(39.7)$ & $307(100)$ & 54.672 & 0.000 & 3 \\
\hline \multirow[t]{2}{*}{ SVI } & Low vulnerability (class III, IV and V) & $111(33.3)$ & $111(33.3)$ & $44(13.2)$ & $67(20.1)$ & $333(100)$ & & & \\
\hline & Total & 201 (31.4) & $149(23.3)$ & $101(15.8)$ & $189(29.5)$ & $640(100)$ & & & \\
\hline
\end{tabular}

*Chi-squared test.

**Hobbies (friends from theater, dances, music activities, sports, and others).

Note: the total number may differ due to missing values. 
Table 2 Binary logistic regression of the binge drinking frequency of "weekly to daily" and "less than monthly to monthly," and the type of friends among adolescents of Belo Horizonte, Minas Gerais, Brazil, 2010

\begin{tabular}{|c|c|c|c|c|c|c|}
\hline \multirow[b]{2}{*}{ All participants } & \multicolumn{3}{|c|}{ Weekly or daily } & \multicolumn{3}{|c|}{ Less than monthly to monthly } \\
\hline & $\begin{array}{l}N \text { of cases } \\
(\%)\end{array}$ & $\begin{array}{l}\text { Odds Ratio } \\
(95 \% \mathrm{CI})\end{array}$ & p-value & $\mathbf{N}$ of cases $(\%)$ & $\begin{array}{l}\text { Odds Ratio } \\
(95 \% \mathrm{Cl})\end{array}$ & p-value \\
\hline $\begin{array}{l}\text { Friends from school vs. } \\
\text { Hobbies/others* }\end{array}$ & $\begin{array}{l}14.4 \\
8.9\end{array}$ & $2.26(1.33-3.85)$ & 0.003 & $36.8(23.2)$ & $2.21(1.51-3.21)$ & $<0.001$ \\
\hline $\begin{array}{l}\text { Friends from family vs. } \\
\text { hobbies/others* }\end{array}$ & $\begin{array}{l}10.1 \\
10.8\end{array}$ & $0.94(0.50-1.74)$ & 0.832 & $28.2(27.3)$ & $1.04(0.68-1.57)$ & 0.869 \\
\hline $\begin{array}{l}\text { Friends from church vs. } \\
\text { Hobbies/others* }\end{array}$ & $\begin{array}{l}6.9 \\
12.2\end{array}$ & $0.42(0.22-0.80)$ & 0.008 & $18.0(31.5)$ & $0.43(0.28-0.66)$ & $<0.001$ \\
\hline $\begin{array}{l}\text { Friends from hobbies vs. } \\
\text { Hobbies/others* }\end{array}$ & $\begin{array}{l}10.9 \\
10.6\end{array}$ & $1.00(0.50-2.01)$ & 0.651 & $25.7(27.8)$ & $0.90(0.55-1.47)$ & 0.358 \\
\hline \multicolumn{7}{|l|}{ Females } \\
\hline $\begin{array}{l}\text { Friends from school vs. } \\
\text { Hobbies/others* }\end{array}$ & $\begin{array}{l}13.1 \\
7.3\end{array}$ & $2.75(1.36-5.53)$ & 0.005 & $40.0(20.6)$ & $2.99(1.87-4.78)$ & $<0.001$ \\
\hline $\begin{array}{l}\text { Friends from family vs. } \\
\text { Hobbies/others* }\end{array}$ & $\begin{array}{l}8.7 \\
9.2\end{array}$ & $0.97(0.44-2.15)$ & 0.939 & $28.2(26.1)$ & $1.10(0.67-1.83)$ & 0.701 \\
\hline $\begin{array}{l}\text { Friends from church vs. } \\
\text { Hobbies/others* }\end{array}$ & $\begin{array}{l}4.6 \\
11.2\end{array}$ & $0.30(0.12-0.73)$ & 0.008 & $16.0(31.5)$ & $0.37(0.22-0.63)$ & $<0.001$ \\
\hline $\begin{array}{l}\text { Friends from hobbies/others vs. } \\
\text { Hobbies/others* }\end{array}$ & $\begin{array}{l}11.3 \\
8.8\end{array}$ & $1.13(0.44-2.90)$ & 0.791 & $17.0(28.0)$ & $0.53(0.25-1.15)$ & 0.107 \\
\hline \multicolumn{7}{|l|}{ Males } \\
\hline $\begin{array}{l}\text { Friends from school vs. } \\
\text { Hobbies/others* }\end{array}$ & $\begin{array}{l}16.9 \\
11.8\end{array}$ & $1.64(0.72-3.74)$ & 0.240 & $31.0(28.3)$ & $1.26(0.66-2.39)$ & 0.482 \\
\hline $\begin{array}{l}\text { Friends from family vs. } \\
\text { Hobbies/others* }\end{array}$ & $\begin{array}{l}13.0 \\
13.6\end{array}$ & $0.94(0.35-2.52)$ & 0.894 & $28.3(29.4)$ & $0.94(0.45-1.96)$ & 0.859 \\
\hline $\begin{array}{l}\text { Friends from church vs. } \\
\text { Hobbies/others* }\end{array}$ & $\begin{array}{l}12.1 \\
13.9\end{array}$ & $0.72(0.29-1.82)$ & 0.489 & $22.4(31.5)$ & $0.59(0.29-1.21)$ & 0.152 \\
\hline $\begin{array}{l}\text { Friends from hobbies vs. } \\
\text { Hobbies/others* }\end{array}$ & $\begin{array}{l}10.4 \\
14.3\end{array}$ & $0.78(0.27-2.25)$ & 0.651 & $35.4(27.4)$ & $1.39(0.69-2.80)$ & 0.358 \\
\hline
\end{tabular}

* Hobbies/others (friends from theater, dances, music activities, sports, and others).

groups of friends from school was associated with a higher likelihood of binge drinking. Individual SES was not associated with binge drinking, but residential SES was associated with binge drinking.

The prevalence of alcohol consumption in our study in Belo Horizonte, Brazil, was similar to previous studies conducted among adolescents in Brazil $[5,56,57]$. However, some studies have reported lower prevalence compared with the present survey $[32,58]$. The prevalence of binge drinking in the present study (36\%) was similar to that reported by studies from other countries (27\%-47\%), and our results are comparable to figures reported previously in Brazil (35\%) [5]. Although the comparison of binge drinking prevalence between countries is somewhat complicated by differences in standard drink sizes and other definitions, the high rates found for alcohol consumption among adolescents represent a significant public health concern. Binge drinking was associated with being an adolescent male, and this result corroborates findings in previous studies $[5,56]$.

Some studies of alcohol consumption and binge drinking in adolescents have shown a statistically significant association with socioeconomic status (family income, personal income and unemployment), but conflicting results have also been reported in the literature. Some studies confirmed that alcohol consumption is negatively associated with socioeconomic status $[59,60]$, while others found positive associations between higher socioeconomic status and high-risk drinking $[56,61]$ as well as low socioeconomic conditions and high-risk drinking [30,32]. Consistent with other studies [55,59-61], our results indicate a higher prevalence of binge drinking among adolescents who live in less vulnerable areas. Also consistent with our results, Humensky (2010) [61] indicated that a higher socioeconomic status in adolescence, as measured by parental education and household income, is associated with higher rates of substance use, particularly binge drinking. Because the SVI also includes family income and educational backgrounds, these results consider the disposable income of those who live in less vulnerable areas where adolescents are more likely to buy their own alcohol and consume it at rates and in quantities without guidance. According to a longitudinal study developed in a representative sample of adolescents in Sweden with multilevel analysis of a period 
Table 3 Ordinal logistic regression of binge drinking and friendship networks, comparing binge drinking frequency of "less than monthly to monthly" frequency with " weekly to daily" with "never" binge drinking among adolescents in Belo Horizonte, Minas Gerais, Brazil ( $\mathrm{n}=\mathbf{8 9 1}$ ), 2010

\begin{tabular}{|c|c|c|c|c|c|c|c|c|c|c|}
\hline & ALL PARTICI & ANTS & & & FEMALE & & & MALE & & \\
\hline & & $\begin{array}{l}\text { Crude OR } \\
(95 \% \mathrm{Cl})\end{array}$ & $\begin{array}{l}\text { Adjusted OR } \\
(95 \% \mathrm{Cl})\end{array}$ & $\begin{array}{l}\text { p-value } \\
\text { Adjusted* }\end{array}$ & $\begin{array}{l}\text { Crude OR } \\
(95 \% \mathrm{Cl})\end{array}$ & $\begin{array}{l}\text { Adjusted OR } \\
(95 \% \mathrm{Cl})\end{array}$ & $\begin{array}{l}\text { p-value } \\
\text { Adjusted* }\end{array}$ & $\begin{array}{l}\text { Crude OR } \\
(95 \% \mathrm{Cl})\end{array}$ & $\begin{array}{l}\text { Adjusted OR } \\
(95 \% \mathrm{Cl})\end{array}$ & $\begin{array}{l}\text { p-value } \\
\text { Adjusted* }\end{array}$ \\
\hline \multirow{4}{*}{$\begin{array}{l}\text { Most Important } \\
\text { groups } \\
\text { of friends } \\
\text { or close friends }\end{array}$} & School & $3.77(2.27-6.25)$ & $3.55(1.91-5.87)$ & $<0.001$ & $4.25(2.25-8.03)$ & $3.70(1.84-7.45)$ & $<0.001$ & $2.91(1.24-6.84)$ & $2.44(0.91-6.46)$ & 0.073 \\
\hline & Family & $1.99(1.16-3.43)$ & $1.79(0.98-3.27)$ & 0.055 & $2.41(1.24-4.72)$ & $2.00(0.96-4.17)$ & 0.064 & $1.34(0.52-3.44)$ & $1.49(0.50-4.50)$ & 0.474 \\
\hline & $\begin{array}{l}\text { **Hobbies/ } \\
\text { others }\end{array}$ & $1.89(1.00-3.57)$ & $1.54(0.78-3.04)$ & 0.207 & $2.11(0.89-4.96)$ & $1.74(0.71-4.29)$ & 0.225 & $1.30(0.49-3.45)$ & $1.12(0.37-3.35)$ & 0.837 \\
\hline & Church & 1.00 & 1.00 & & 1.00 & 1.00 & & 1.00 & 1.00 & \\
\hline \multirow{2}{*}{$\begin{array}{l}\text { Majority of friends that } \\
\text { have the same work or } \\
\text { occupation }\end{array}$} & Yes & $1.57(1.08-2.29)$ & $1.25(0.79-1.98)$ & 0.340 & $1.60(1.00-2.54)$ & $1.20(0.67-2.16)$ & 0.538 & $1.50(0.80-2.83)$ & $1.31(0.59-2.94)$ & 0.505 \\
\hline & No & 1.00 & 1.00 & & 1.00 & 1.00 & & 1.00 & 1.00 & \\
\hline \multirow{2}{*}{$\begin{array}{l}\text { Educational background } \\
\text { or level for the majority } \\
\text { of friends }\end{array}$} & Yes & $1.40(0.94-2.08)$ & $0.73(0.44-1.18)$ & 0.200 & $1.53(0.93-2.51)$ & $0.80(0.43-1.50)$ & 0.492 & $1.17(0.59-2.31)$ & $0.63(0.27-1.46)$ & 0.282 \\
\hline & No & 1.00 & 1.00 & & 1.00 & 1.00 & & 1.00 & & \\
\hline \multirow{2}{*}{$\begin{array}{l}\text { Number of groups } \\
\text { of friends }\end{array}$} & $<2$ & $1.25(0.84-1.85)$ & $1.37(0.89-2.11)$ & 0.143 & $1.01(0.62-1.65)$ & $1.14(0.68-1.93)$ & 0.618 & $2.15(1.06-4.36)$ & $2.21(1.00-4.87)$ & 0.049 \\
\hline & $\geq 2$ & 1.00 & 1.00 & & 1.00 & & & 1.00 & 1.00 & \\
\hline \multirow[t]{3}{*}{ Age } & $15-16$ & $0.98(0.65-1.49)$ & $0.82(0.44-1.52)$ & 0.524 & $0.84(0.36-1.95)$ & $0.66(0.27-1.59)$ & 0.358 & $0.95(0.41-2.20)$ & $0.88(0.35-2.21)$ & 0.793 \\
\hline & 17 & $1.17(0.74-1.84)$ & $1.48(0.76-2.86)$ & 0.245 & $1.31(0.54-3.19)$ & $1.01(0.40-2.54)$ & 0.974 & $2.22(0.87-5.71)$ & $2.44(0.90-6.63)$ & 0.081 \\
\hline & 18-19 & 1.00 & 1.00 & & 1.00 & & & & & \\
\hline \multirow{2}{*}{$\begin{array}{l}\text { Mother's educational } \\
\text { background }\end{array}$} & $0-7$ years & $0.66(0.45-0.98)$ & $0.94(0.56-1.58)$ & 0.825 & $0.63(0.39-1.01)$ & $1.01(0.52-1.95)$ & 0.970 & $0.78(0.40-1.51)$ & $0.87(0.36-2.11)$ & \\
\hline & 8 or more & 1.00 & 1.00 & & 1.00 & 1.00 & & 1.00 & 1.00 & \\
\hline \multirow{2}{*}{$\begin{array}{l}\text { Father's educational } \\
\text { background }\end{array}$} & $0-7$ years & $0.60(0.43-0.83)$ & $1.08(0.65-1.80)$ & 0.751 & $0.61(0.38-0.97)$ & $0.93(0.48-1.79)$ & 0.830 & $0.88(0.47-1.63)$ & $1.47(0.63-3.43)$ & 0.376 \\
\hline & 8 or more & 1.00 & 1.00 & & 1.00 & 1.00 & & 1.00 & 1.00 & \\
\hline \multirow[t]{2}{*}{ Type of school } & Public & $0.60(0.40-0.89)$ & $0.74(0.45-1.23)$ & 0.245 & $0.59(0.36-0.96)$ & $0.80(0.43-1.49)$ & 0.485 & $0.64(0.33-1.25)$ & $0.63(0.30-1.35)$ & 0.236 \\
\hline & Private & 1.00 & 1.00 & & 1.00 & 1.00 & & 1.00 & 1.00 & \\
\hline \multirow[t]{2}{*}{ IVS } & $\begin{array}{l}\text { Low } \\
\text { Vulnerability }\end{array}$ & $1.66(1.15-2.41)$ & $1.66(1.05-2.62)$ & 0.028 & $1.83(1.46-2.92)$ & $1.62(0.90-2.92)$ & 0.104 & $1.48(0.80-2.76)$ & $1.97(0.90-4.32)$ & 0.089 \\
\hline & $\begin{array}{l}\text { Great } \\
\text { Vulnerability }\end{array}$ & 1.00 & 1.00 & & 1.00 & 1.00 & & 1.00 & 1.00 & \\
\hline \multirow[t]{2}{*}{ Gender } & Male & $1.24(0.94-1.62)$ & $1.52(1.01-2.28)$ & 0.044 & & & & & & \\
\hline & Female & 1.00 & 1.00 & & & & & & & \\
\hline
\end{tabular}

* Adjusted for age, sex, type of school, mother's education and Social Vulnerability Index (SVI).

**Hobbies/others (friends from theater, dances, music activities, sports, and others). 
with large economic changes, unemployment is statistically associated with binge drinking [3]. A decrease in incomes leads to lower consumption of all goods, including alcohol because adolescents have to allocate the resources they can spend on different goods [3].

In this paper, we estimated the predictors of adolescent drinking behavior to identify the role of social friendship networks on binge drinking. Adolescents who reported that the majority of their groups of friends/close friends were from school rather than from church or hobbies/ other activities had higher odds of binge drinking. This result corroborates finding in the National Longitudinal Study of Adolescent Health in the US, suggesting that an increase of $10 \%$ in the proportion of classmates who drink will increase the likelihood of drinking among peers by $4 \%$ [12]. With similar results, a classroom-randomized controlled trial that compared control classes with those receiving an evidence-based substance use (including alcohol) prevention program with 541 adolescents in the US indicated that students with classroom friends who used substances were more likely to increase their own use [10]. However, our study revealed that differences emerged when analyses were conducted separately by gender. In our study, the adolescent females who reported that the majority of their groups of close friends were from school had a higher likelihood of binge drinking compared with those who reported that their best friends were from church or from hobbies and other activities. However, no statistically significant association was found for male adolescents. These results are consistent with previous evidence of the importance of friends on alcohol drinking in adolescence. At least two studies have demonstrated that peer drinking has a greater impact on the average amount of alcohol consumed by girls consumed versus the amount consumed by boys [53,62]. Furthermore, girls are more likely to socialize with and be persuaded by friends to drink alcohol compared with boys [55].

When we compared the adolescents who reported that the majority of their groups of close friends were from church with the adolescents who reported that the majority of their groups of close friends were from hobbies and other activities, we found that having friends from church was associated with less binge drinking. This result is similar to that found using other surveys, which suggest the association between attending church/religiosity and a lower likelihood of binge drinking $[5,20,63,64]$. However, because we did not collect information on the adolescents' religious beliefs or church attendance frequency, we were unable to tease out the relative contributions of having friends in church-based networks versus religious participation or religious beliefs.

Studies developed by Valente et al. (2007) [10]; Jamison and Myers (2008) [11]; Kiuru et al. (2010) [13], previously examined the influence of the peer group on alcohol consumption in adolescents, but they were limited to investigating just the school based peer network. Other studies investigated the influence of the peer group on alcohol consumption in adolescents based on their religiosity or church attendance $[5,63]$. We are not aware of a previous study that compared the different type of groups of friends from different contexts in relation to alcohol consumption by adolescents. It is important to consider friendship networks in multiple contexts when examining peer influences on adolescent behavior. Our study was not restricted to nominated peer groups, so it was possible to compare groups of friends from different contexts such as church, school, family and hobby groups. Comparing the different sources of peer connections, we found that adolescent binge drinking was strongly associated with school-based friendship networks relative to church-based networks.

Throughout the course of a lifetime, friendships can direct development through support, modeling, and assistance, but their significance is heightened during adolescence [14]. Peers have the potential to both positively and negatively influence behavior, depending on the behavior endorsed by the peer group [15].

Public health interventions targeted to the peer network might be more cost-effective than previous estimates have suggested because the health-promoting behavior of one person may spread to others via social networks $[10,12]$. The extent to which the school is a functional community with supportive social relationships, social participations in school activities, and shared norms, goals, and values may also moderate the individual risk of initiating adverse health behaviors such as high alcohol consumption [65]. Our results showed that students having their most important group of friends coming from church seems to be a protective factor with respect to binge drinking. The protective effect of social capital might reflect the effect of norms and social controls on curtailing deviant and dangerous alcohol consumption in communities in which individuals are more bonded to each other [66]. Thus, our findings underscore the importance of deeply exploring how the context can determine alcohol consumption.

Our results should be interpreted while considering some limitations. Because this study of the association between type of friendship network and binge drinking used cross-sectional data, two principal threats to causal inference should be considered: homophily and unobserved confounding. Homophily refers to the idea that individuals select different types of social network connections based partly on their own behavior preferences. For example, some students may enjoy associating with others based on their shared preference for observing religious proscriptions against drinking alcohol. In other words, the associations that we observed may have been driven by the tendency for "birds of a feather to flock together", rather than by the network characteristics per se (e.g., social norms 
that influence and regulate behaviors within certain types of social networks). Secondly, our finding may reflect the influence of unmeasured confounding factors that affect both patterns of friendship networks and drinking behavior. For example, the strictness of school policies against drinking may influence both the formation of different friendship connections as well as the prevalence of binge drinking. Because we did not collect information on variables such as school policies, we cannot rule out the possibility that unmeasured or unobserved factors could have led to the patterns we observed.

We did not measure and control for variables such as "parental supervision" in our survey. Thus, if students who associated with peers from school were also those who were less likely to be supervised by their parents, the association between having school friends and binge drinking could have been confounded by such omitted variables.

We assured the participants in this study that their responses would remain anonymous. However, there are some limitations associated with our measures of behaviors and negative outcomes because they rely on selfreports of alcohol consumption and binge drinking. It is possible that the actual amount of alcohol consumption and binge drinking could have been either underreported or exaggerated. Furthermore, our sampling approach did not include individuals who were excluded from or had otherwise left school-based education, and the Vulnerability Index (SVI) was calculated on an ecologic level and not on an individual basis.

The level of social capital to which an individual may gain access through their social networks depends on the structural characteristics of the networks as well as on the amount of social capital that other individuals in the network possess. Although they may be positive, friendship networks can also be viewed as negative, especially with regard to binge drinking during adolescence. Corroborating our results, at least three other studies have also found an association between peer influence and alcohol consumption and binge drinking $[10,11,13]$.

We were unable to obtain information on the size, density, quality, or proximity of the friendship network or the normative drinking behaviors within those networks. Further studies are needed to investigate the importance of the detailed characteristics of friendship networks (size, density, quality, and proximity), parental control, religious beliefs and participation. Another important issue for future research is to measure the perceived norms among different types of friendships. Ideally, studies should measure the subjective norms surrounding drinking behavior within school-based versus church-based networks (e.g., "How frequently do my friends from school/church engage in binge drinking?" and "Do my friends (in school or in my church group) approve/disapprove of drinking?”).

\section{Conclusions}

The findings of this study highlight the association between social network (type of friends) and risky drinking behavior among adolescents, the importance of which is underscored in countries like Brazil that have a high prevalence of alcohol consumption and binge drinking among adolescents. This study revealed that the type of group of friends with which an adolescent associates and gender may determine the likelihood that an individual consumes large amounts of alcohol. Therefore, interventions to reduce alcohol consumption in adolescents should consider both the friendship network characteristics and gender.

\section{Competing interests}

The authors declare that they have no competing interests.

\section{Author details}

${ }^{1}$ Department of Pediatric Dentistry and Orthodontics, Faculty of Dentistry, Universidade Federal de Minas Gerais, Av. Antonio Carlos, 6627 CEP: 31270901, Belo, Horizonte/MG, Brazil. 'Department of Society, Human Development, and Health, Harvard School of Public Health, 677 Huntington Avenue, Boston, MA02115-6096, USA. ${ }^{3}$ Department of Oral Public Health, Faculty of Dentistry, Universidade Federal de Minas Gerais, Av. Antonio Carlos, 6627 CEP: 31270901, Belo, Horizonte/MG, Brazil.

\section{Authors' contributions}

$\mathrm{PZ}, \mathrm{KJ}, \mathrm{MV}$, and EF conceived of the study. KJ collected data. PZ conducted the analysis and wrote the first version. TO and IK contributed substantially to the interpretation of the results. KJ, TO, MV, EF and IK revised the manuscript for important intellectual content. All authors read and approved the final version of the manuscript.

\section{Funding}

This study was supported by the Brazilian Council for Scientific and Technological Development (CNPq) and FAPEMIG. The funders had no role in the study design, data collection and analysis, decision to publish or preparation of the manuscript.

Received: 22 December 2011 Accepted: 2 April 2012

Published: 2 April 2012

\section{References}

1. Assanangkornchai S, Mukthong A, Intanont T: Prevalence and patterns of alcohol consumption and health-risk behaviors among high school students in Thailand. Alcohol Clin Exp Res 2009, 33:2037-2046.

2. Viner R, Taylor B: Adult outcome of binge drinking in adolescence: findings from a UK national birth cohort. J Epidemiol Community Health 2007, 61:902-907.

3. Svensson M, Hagquist C: Adolescents' alcohol-use and economic conditions: a multilevel analysis of data from a period with big economic changes. Eur J Health Econ 2010, 11:533-541.

4. Stolle M, Sack P, Thomasius R: Binge drinking in childhood and adolescence. Dsch Arztebl Int 2009, 106:323-328.

5. Sanchez ZM, Martins SS, Opaleye ES, Moura YG, Locatelli DP, Noto AR: Social factors associated to binge drinking: a cross-sectional survey among Brazilian students in private high schools. BMC Public Health 2011, 11:201.

6. Romano M, Duailibi S, Pinsky I, Laranjeira R: Alcohol purchase survey by adolescents in two cities of State of São Paulo, Southeastern Brazil. Rev Saude Publica 2007, 41:495-501.

7. Coleman LG, He J, Lee J, Styner M, Crews FT: Adolescent binge drinking alters adult brain neurotransmitter gene expression, behavior, brain regional volumes, and neurochemistry in mice. Alcohol Clin Exp Res 2011, 35:671-688.

8. Pletcher MJ, Varosy P, Kiefe Cl, Lewis CE, Sidney S, Hulley SB: Alcohol consumption, binge drinking, and early coronary calcification: findings from the Coronary Artery Risk Development in Young Adults (CARDIA) Study. Am J Epidemiol 2005, 161:423-433.

9. Ezzati M, Lopes A, Rodgers A, Murray C: Comparative quantification of health risks: global and regional burden of disease attributed to selected major risk 
factors. World Health Organization: Geneva; 2004

10. Valente T, Ritt-Olson A, Stacy A, Unger J, Okamoto J, Sussman S: Peer acceleration: effects of a social network tailored substance abuse prevention program among high-risk adolescents. Addiction 2007, 102:1804-1815.

11. Jamison J, Myers L: Peer-group price influence students drinking along with planned behavior. Alcohol Alcohol 2008, 43:492-497.

12. Ali M, Dwyer D: Social network effects in alcohol consumption among adolescents. Addict Behav 2010, 35:337-342.

13. Kiuru N, Burk W, Laursen B, Salmela-Aro K, Nurmi J: Pressure to drink but not to smoke: disentangling selection and socialization in adolescent peer networks and peer groups. J Adolesc 2010, 33:801-812

14. Hartup W, Stevens N: Friendship and adaptation in the life course. Psychol Bull 1997, 121:355-370.

15. Rosenquist J, Murabito J, Fowler J, Christakis N: The spread of alcohol consumption behavior in a large social network. Ann Intern Med 2010, 152:426-433

16. Brown B, Bakken J, Ameringer S, Mahon S: A comprehensive conceptualization of the peer influence process in adolescence. In Understanding peer influence in children and adolescence. 1st edition. Edited by Prinstein MJ, Dodge KA. New York: Guilford Press; 2008:17-44.

17. Johansen A, Rasmussen S, Madsen M: Health behavior among adolescents in Denmark: influence of school class and individual risk factors. Scand J Public Health 2006, 34:32-40.

18. West $P$, Sweeting $H$, Leyland A: School effects on pupils' health behaviors: evidence in support of the health promotion school. Res Papers Educ 2004, 19:261-291.

19. Valente TW, Gallaher P, Maittapa M: Using social network to understand and prevent substance use: a transdiciplinary perspective. Subst Use Misuse 2004, 39:1685-1712.

20. Stevens-Watkins D, Rostosky S: Binge drinking in African American males from adolescence to young adulthood: the protective influence of religiosity, family connectedness and close friends' substance use. Subst Use Misuse 2010, 45:1435-1451.

21. Carter AC, Brandon KO, Goldman MS: The college and noncollege experience: a review of the factors that influence drinking behavior in young adulthood. J Stud Alcohol Drugs 2010, 71:742-750

22. Brazilian Institute of Geography and Statistics (IBGE): 2010 population census. [http://www.ibge.gov.br/home/estatistica/populacao/contagem].

23. Daniel WW: Biostatistics: A Foundation for Analysis in the Health Sciences. 7th edition. New York: John Wiley \& Sons; 1999.

24. Lwanga SK, Lemeshow S: Sample Size Determination in Health Studies: A Practical Manual. Geneva: World Health Organization; 1991.

25. Kirkwood BR, Stern J: Essentials of medical statistics. London: Blackwell; 2003.

26. Chung T, Colby S, Barnett N, Rohsenow D, Spirito A, Monti P: Screening adolescents for problem drinking: performance of brief screens against DSM-IV alcohol diagnoses. J Stud Alcohol 2000, 61:579-587.

27. Kelly T, Donovan J, Kinnane J, Taylor D: A comparison of alcohol screening instruments among under-aged drinkers treated in emergency departments. Alcohol Alcohol 2002, 37:444-450.

28. Reinert D, Allen J: The Alcohol Use Disorders Identification Test: an update of research findings. Alcohol Clin Exp Res 2007, 31:185-199.

29. Lima CT, Freire AC, Silva AP, Teixeira RM, Ferrell M, Prince M: Concurrent and construct validity of the AUDIT in an urban Brazilian sample. Alcohol Alcohol 2005, 40:584-589.

30. Mendoza-Sassi RA, Béria JU: Prevalence of alcohol use disorders and associated factors: a population-based study using AUDIT in southern Brazil. Addiction 2003, 98:799-804

31. Jorge KO, Oliveira Filho PM, Ferreira EF, Oliveira AC, Vale MP, Zarzar PM: Prevalence and association of dental injuries with socioeconomic conditions and alcohol/drug use in adolescents between 15 and 19 years of age. Dent Traumatol, in press.

32. Pinsky I, Sanches M, Zaleski M, Laranjeira R, Caetano R: Patterns of alcohol use among Brazilian adolescents. Rev Bras Psiquiatr 2010, 32:242-249.

33. Courtney K, Polich J: Binge drinking in young adults: data, definitions and determinants. Psychol Bull 2009, 135:142-156.

34. Grootaert C, Narayan D, Jones V, Woolcook M: Measuring social capital: an Integrated Questionnaire. Virginia, World Bank: Washington DC; 2003.

35. Nahas M, Ribeiro C, Esteves O, Moscovitch S, Martins V: O mapa da exclusão social de Belo Horizonte: metodologia de construção de um instrumento de gestão urbana. Cad Cienc Soc 2000, 7:75-88 [in Portuguese]
36. Bonanato K, Paiva SM, Pordeus IA, Ramos-Jorge ML, Barbabela D, Allison PJ: Relationship between mothers' sense of coherence and oral health status of preschool children. Caries Res 2009, 43:103-109.

37. Serra-Negra JM, Ramos-Jorge ML, Flores-Mendoza CE, Paiva SM, Pordeus IA Influence of psychosocial factors on the development of sleep bruxism among children. Int J Paediatr Dent 2009, 19:309-317.

38. Braga LS, Macinko J, Proietti FA, César CC, Lima-Costa MF: Intra-urban differences in vulnerability among the elderly population. Cad Saude Publica 2010, 26:2307-2315.

39. Carvalho AC, Paiva SM, Scarpelli AC, Viegas CM, Ferreira FM, Pordeus IA: Prevalence of malocclusion in primary dentition in a population-based sample of Brazilian preschool children. Eur J Paediatr Dent 2011, 12: 107-111.

40. Turci MA, Lima-Costa MF, Proietti FA, Cesar CC, Macinko J: Intraurban differences in the use of ambulatory health services in a large Brazilian city. J Urban Health 2010, 87:994-1006.

41. Jorge KO, Moysés SJ, Ferreira E-Ferreira E, Ramos-Jorge ML, De Araújo Zarzar PM: Prevalence and factors associated to dental trauma in infants 1-3 years of age. Dent Traumatol 2009, 25:185-189.

42. Ozgür I, Yildirim F, Demirbaş H, Doğan YB: Alcohol use prevalence and sociodemographic correlates of alcohol use in a university student sample in Turkey. Soc Psychiatry Psychiatr Epidemiol 2008, 43:575-583.

43. Melotti R, Heron J, Hickman M, Macleod J, Araya R, Lewis G: ALSPAC Birth Cohort: Adolescent alcohol and tobacco use and early socioeconomic position: the ALSPAC birth cohort. Pediatrics 2011, 127:948-955.

44. Bachman JG, O'Malley PM, Johnston LD, Schulenberg JE, Wallace JM: Racial/ ethnic differences in the relationship between parental education and substance use among U.S. 8th-, 10th-, and 12th-grade students: findings from the Monitoring the Future project. J Stud Alcohol Drugs 2011, 72:279-85

45. Moreira PV, Rosenblatt A, Passos IA: Prevalence of cavities among adolescents in public and private schools in João Pessoa, Paraíba State, Brazil. Cien Saude Colet 2007, 12:1229-1236.

46. Hoffmann RH, Cypriano S, Sousa ML, Wada RS: Dental caries experience in children at public and private schools from a city with fluoridated water. Cad Saude Publica 2004, 20:522-528.

47. Antunes JL, Peres MA, de Campos Mello TR, Waldman EA: Multilevel assessment of determinants of dental caries experience in Brazil. Community Dent Oral Epidemiol 2006, 34:146-152.

48. Tomé FS, Cardoso VC, Barbieri MA, Silva AA, Simões VM, Garcia CA, Bettiol H: Are birth weight and maternal smoking during pregnancy associated with malnutrition and excess weight among school age children? Braz $J$ Med Biol Res 2007, 40:1221-1230.

49. Claro LB, March C, Mascarenhas MT, de Castro IA, Rosa ML: Adolescents and their relationship to health services: a school-based cross-sectional study in Niterói, Rio de Janeiro, Brazil. Cad Saude Publica 2006, 22:1565-1574.

50. Piovesan C, Pádua MC, Ardenghi TM, Mendes FM, Bonini GC: Can type of school be used as an alternative indicator of socioeconomic status in dental caries studies? A cross-sectional study. BMC Med Res Methodol 2011, 11:37

51. De Carlo LT: Using the PLUM procedure of SPSS to fit unequal variance and generized signal detection models. Behav Res Methods Instrum Comput 2003, 35:49-56.

52. Lall R, Campbell MJ, Walters SJ, Morgan K: A review of ordinal regression models applied on health - related quality of life assessments. Stat Methods Med Res 2002, 11:49-67.

53. Danielsson AK, Romelsjo A, Tengstrom A: Heavy episodic drinking in early adolescence: gender-specific risk and protective. Subst Use Misuse 2011, 46:633-643.

54. Sychareun V, Thomsen S, Faxelid E: Cuncurrent multiple health risk behavior among adolescents in Laungnantha province. Lao PDR. BMC Public Health 2011, 11:36.

55. Freisthler B, Gruenewald PJ, Treno AJ, Lee J: Evaluating alcohol access and the alcohol environment in neighborhood areas. Alcohol Clin Exp Res 2003, 27:477-484

56. Almeida-Filho N, Lessa I, Magalhães L, Araújo M, Aquino E, Kawachi I, James S: Alcohol drinking patterns by gender, ethnicity, and social class in Bahia, Brazil. Rev Saude Publica 2004, 38:45-54.

57. Carlini EA, Galduróz JF, Noto AR, Fonseca AM, Carlini CM, Oliveira LG; Nappo AS, Moura YG, Sanchez ZM: II Levantamento Domiciliar sobre o Uso de Drogas Psicotrópicas no Brasil: estudo envolvendo as 108 
maiores cidades do país - 2005 - Centro Brasileiro de Informações sobre Drogas Psicotrópicas (CEBRID) - Universidade Federal de São Paulo (UNIFESP) - 2005

58. Bastos F, Bertoni N, Harcker M: Drug and Alcohol use: main findings of a national survey, Brazil 2005. Rev Saude Publica 2008, 42:109-117.

59. Lundborg P: Social capital and substance use among Swedish adolescents-an explorative study. Soc Sci Med 2005, 61:1151-1158.

60. Barros M, Botega N, Dalgalarrondo P, Marín-Léon L, Oliveira H: Prevalence of alcohol abuse and associated factors in a population-based study. Rev Saude Publica 2007, 41:502-509.

61. Humensky J: Are adolescents with high socioeconomic status more likely to engage in alcohol and illicit drug use in early adulthood? Subst Abuse Treat Prev Policy 2010, 5:19.

62. Anderson KG, Tomlinson $\mathrm{K}$, Robinson JM, Brown SA: Friends or foes: social anxiety, peer affiliation, and drinking in middle school. J Stud Alcohol Drugs 2011, 72:61-69.

63. Bahr S, Hoffmann JP: Parenting style, religiosity, peers, and adolescent heavy drinking. J Stud Alcohol Drugs 2010, 71:539-543.

64. Yeung JWK, Chan Y, Lee BL: Youth religiosity and substance use: a meta-analysis from 1995 to 2007. Psychol Rep 2009, 105:255-266.

65. McMillan D, Chavis D: Sense of community: a definition and theory. J Community Psycol 1986, 14:6-23.

66. Weitzman E, Kawachi I: Giving means receiving: the protective effect of social capital on binge drinking on college campuses. Am J Public Health 2000, 90:1936-1939.

doi:10.1186/1471-2458-12-257

Cite this article as: Zarzar et al: Association between binge drinking type of friends and gender: A cross-sectional study among Brazilian adolescents. BMC Public Health 2012 12:257.

\section{Submit your next manuscript to BioMed Central and take full advantage of:}

- Convenient online submission

- Thorough peer review

- No space constraints or color figure charges

- Immediate publication on acceptance

- Inclusion in PubMed, CAS, Scopus and Google Scholar

- Research which is freely available for redistribution 